\title{
高温 $\mathrm{X}$ 線単結晶法による $\mathrm{Ca}_{2} \mathrm{SiO}_{4}$ の相転移の研究
}

\author{
宇田川重和・浦部和順・矢野豊彦・夏目 幹子* \\ ( $\left.\begin{array}{c}\text { 東京工業大学 工学学部 } \\ * \text { 無機材料工学科 }\end{array}\right)$
}

$\mathrm{Ca}_{2} \mathrm{SiO}_{4}$ の相転移を高温プリセッションカメラを用いて研究し， $\mathrm{Ca}_{2} \mathrm{SiO}_{4}$ の多形間の相転移にお いて共軸関係が保たれることが明らかとなった. 得られた結果を総括すると以下のようになる.

(1) $\gamma \rightarrow \alpha^{\prime} \mathrm{L}$ 相転移では $a_{\gamma} / / a_{\alpha^{\prime} \mathrm{L}}, b_{\gamma} / / b_{\alpha^{\prime} \mathrm{L}}, c_{\gamma} / / c_{\alpha^{\prime} \mathrm{L}}$ の共軸関係が保たれる.

(2) $\alpha_{\mathrm{L}}^{\prime} \rightarrow \alpha^{\prime}{ }_{\mathrm{H}}$ 相転移では $a_{\alpha^{\prime} \mathrm{L}} / / a_{\alpha^{\prime} \mathrm{H}}, b_{\alpha^{\prime} \mathrm{L}} / / b_{\alpha^{\prime} \mathrm{H}}, c_{\alpha^{\prime} \mathrm{L}} / / c_{\alpha^{\prime} \mathrm{H}}$ の共軸関係が保たれるが, $\alpha_{\mathrm{L}}^{\prime}$ 相 の超格子反射の回折強度は温度の上昇とともに減少する.

(3) $\quad \alpha_{\mathrm{L}}^{\prime} \rightarrow \beta$ 相転移では， $a_{\alpha^{\prime} \mathrm{L}} / / a^{*}{ }_{\beta}, b_{\alpha^{\prime} \mathrm{L}} / / c_{\beta}, c_{\alpha^{\prime} \mathrm{L}} / / b_{\beta}$ の共軸関係が保たれる. なおこの相転 移で生成した $\beta$ 相の結晶中には (100) 双晶がしばしば観察された.

(4) $\beta \rightarrow \gamma$ 相転移では, $a^{*}{ }_{\beta} / / a_{\gamma}, b_{\beta} / / c_{\gamma}, c_{\beta} / / b_{\gamma}$ の共軸関係が保たれる.

上述の共軸関係及び $\mathrm{Ca}_{2} \mathrm{SiO}_{4}$ の各多形の結晶構造に基づき, $\mathrm{Ca}_{2} \mathrm{SiO}_{4}$ の相転移の機構を論じ，更 に相転移の間に起こる原子移動の観点からこの機構を明らかにした.

(1979 年 10 月 4 日受付)

\section{Studies on the Phase Transitions of $\mathrm{Ca}_{2} \mathrm{SiO}_{4}$ by X-ray Single Crystal Camera with a High Temperature Apparatus}

\author{
Shigekazu UDAGAWA, Kazuyori URABE, Toyohiko YANO and Mikiko NATSUME* \\ (Department of Inorganic Materials, Fuculty of Engineering, \\ Tokyo Institute of Technology, Meguro-ku 152 \\ * Present : Tokoha Gakuen, Shizuoka-shi 420
}

The phase transitions of $\mathrm{Ca}_{2} \mathrm{SiO}_{4}$ have been investigated by the precession camera with a high temperature apparatus. The topotaxial relations are maintained through the phase transitions among the modifications of $\mathrm{Ca}_{2} \mathrm{SiO}_{4}$. The results obtained are summarized as follows :

(1) For $\gamma \rightarrow \alpha_{\mathrm{L}}^{\prime}$ transition, $a_{\gamma} / / a_{\alpha^{\prime} \mathrm{L}}, b_{\gamma} / / b_{\alpha^{\prime} \mathrm{L}}, c_{\gamma} / / c_{\alpha^{\prime} \mathrm{L}}$.

(2) For $\alpha_{\mathrm{L}}^{\prime} \rightarrow \alpha_{\mathrm{H}}^{\prime}$ transition, $a_{\alpha^{\prime} \mathrm{L}} / / a_{\alpha^{\prime} \mathrm{H}}, b_{\alpha_{\mathrm{L}}^{\prime} \mathrm{L}} / / b_{\alpha^{\prime} \mathrm{H}}, c_{\alpha^{\prime} \mathrm{L}} / / c_{\alpha^{\prime} \mathrm{H}}$. The intensities of the superstructure reflections of $\alpha^{\prime}{ }_{L}$-phase decrease with increasing temperature during the $\alpha^{\prime}$ $\rightarrow \alpha^{\prime}{ }_{\mathrm{H}}$ transition.

(3) For $\alpha^{\prime}{ }_{L} \rightarrow \beta$ transition, $a_{\alpha^{\prime} \mathrm{L}} / / a_{\beta}^{*}, b_{\alpha^{\prime} \mathrm{L}} / / c_{\beta}, c_{\alpha^{\prime} \mathrm{L}} / / b_{\beta}$. (100) twin is often observed in the $\beta$-phase crystal formed by the $\alpha^{\prime}{ }_{L} \rightarrow \beta$ transition.

(4) For $\beta \rightarrow \gamma$ transition, $a^{*}{ }_{\beta} / / a_{\gamma}, b_{\beta} / / c_{\gamma}, c_{\beta} / / b_{\gamma}$.

On the basis of the topotaxial relations through the phase transitions and the crystal structures of the modifications of $\mathrm{Ca}_{2} \mathrm{SiO}_{4}$, the mechanisms of the phase transitions of $\mathrm{Ca}_{2} \mathrm{SiO}_{4}$ have been discussed in terms of the movements of atoms during the transitions.

[Received October 4, 1979]

Key-words : $\mathrm{Ca}_{2} \mathrm{SiO}_{4}$, Belite, Phase transition, Topotaxial relation, Dusting

\section{1. 緒言}

$\mathrm{Ca}_{2} \mathrm{SiO}_{4}$ を主成分とする固溶体は, セメントクリンカ 一，転炉スラグなどの主要構成鉱物の一つである. 純粋 な $\mathrm{Ca}_{2} \mathrm{SiO}_{4}$ には, 常圧下で $\alpha, \alpha_{\mathrm{H}}^{\prime}, \alpha_{\mathrm{L}}^{\prime}, \beta$ 及び $\gamma$ の 5 種の多形が存在し1) (表 1 ), 更に高圧下で新相が生成
することが報告されている22. これら多形間の相転移は 複雑難解であり，これを解明することはセメントやスラ グに関連する科学並びに工学において 極めて 重要であ る.

常圧下で生成する 5 種の多形のらち， $\gamma$ 相はオリビン 
Table 1. Crystallographic data of the five modifications of $\mathrm{Ca}_{2} \mathrm{SiO}_{4}$ (*after Regourd et al. ${ }^{7)}$ ).

\begin{tabular}{|c|c|c|c|c|c|}
\hline rhase & $\gamma$ & $B$ & $\alpha^{\prime} L$ & $\alpha_{\mathrm{H}}^{\prime}$ & $\alpha$ \\
\hline $\begin{array}{l}\text { space } \\
\text { group }\end{array}$ & $\begin{array}{c}\text { orthorhombic } \\
\text { Pbnm }\end{array}$ & $\begin{array}{l}\text { monoclinic } \\
\mathrm{P} 121 / \mathrm{n} 1\end{array}$ & $\begin{array}{l}\text { orthorhombic } \\
\mathrm{P}_{1}{ }_{1} \mathrm{cn}\end{array}$ & $\begin{array}{l}\text { orthorhomb1c } \\
\text { Pmen }\end{array}$ & $\begin{array}{l}\text { hexagonal } \\
\mathrm{P}_{3} / \mathrm{mmc}\end{array}$ \\
\hline $\begin{array}{l}\text { type of } \\
\text { structure }\end{array}$ & olivine & $\begin{array}{r}\text { marked1y } \\
\text { deformed } \\
\mathrm{B}^{-} \mathrm{K}_{2} \mathrm{SO}_{4} \\
\end{array}$ & \multicolumn{2}{|c|}{$\begin{array}{c}\text { slightly deformed } \\
\beta-\mathrm{K}_{2} \mathrm{SO}_{4}\end{array}$} & $\begin{array}{l}\text { domain } \\
\text { structure }\end{array}$ \\
\hline $\begin{array}{l}\text { lattice } \\
\text { constants }\end{array}$ & $\begin{array}{l}a=5.081(2) \AA \\
b=11.224(5) \\
c=6.778(10)\end{array}$ & $\begin{array}{l}a=5.513(2) \AA \\
b=6.763(1) \\
c=9.321(2) \\
\beta=94.55(1)^{\circ}\end{array}$ & $\begin{array}{l}a=5.553(2) \AA \\
b=9.339(2) \\
c=6.812(3) \times 3\end{array}$ & $\begin{array}{c}* a=5.593 \AA \\
b=9.535 \\
c=6.860\end{array}$ & $\begin{array}{l}a=5.579 \AA \\
c=7.150\end{array}$ \\
\hline $\begin{array}{c}\text { cell } \\
\text { volume }\end{array}$ & $V=386.5 \AA^{3}$ & $V=346.4 \AA^{3}$ & $V=353.3 \times 3 \AA^{3}$ & $V=365.8 \AA^{3}$ & $V=385.5 \times \frac{1}{2} \AA^{3}$ \\
\hline $\begin{array}{c}\mathrm{Ca} \\
\text { coordinates }\end{array}$ & $\begin{array}{l}\mathrm{Ca}(1)=6 \\
\mathrm{Ca}(2)=6\end{array}$ & $\begin{array}{l}\mathrm{Ca}(1)=10 \\
\mathrm{Ca}(2)=8\end{array}$ & $\begin{array}{l}\mathrm{Ca1}(\mathrm{n})=10 \\
\operatorname{Ca2}(\mathrm{n})=7\end{array}$ & $\begin{array}{l}\mathrm{Ca}(1)=10 \\
\mathrm{Ca}(2)=7\end{array}$ & $\begin{array}{l}\mathrm{Ca}(1)=10 \\
\mathrm{Ca}(2)=6 / 12\end{array}$ \\
\hline
\end{tabular}

型構造であり，室温で水和活性を示さない唯一の相であ る. $\beta$ 相はひずんだ $\beta-\mathrm{K}_{2} \mathrm{SO}_{4}$ 型の結晶構造であること が Midgley ${ }^{3)}$ によって明らかにされ，その後 Jost ら ${ }^{4)}$ ， 及び宇田川ら (5), () によって精密な結晶構造解析が行われ た. $\alpha^{\prime}{ }_{\mathrm{L}}$ 相と $\alpha^{\prime}{ }_{\mathrm{H}}$ 相は, それらの粉末 $\mathrm{X}$ 線回折眓形を 詳細に 解析することにより判別し得ることが Regourd ら゙によって明らかにされた。 なお Saalfeld ${ }^{8)}$ は $\alpha^{\prime}{ }_{L}$ 相 の格子定数を高温単結晶カメラを用いて求めている. 宇 田川ら ${ }^{9)} は, S r$ で安定化した $\alpha^{\prime}{ }_{L}$ 相の結晶構造を単結 晶自動 $\mathrm{X}$ 線回折計を用いて解析し，それがわずかにひず んだ $\beta-\mathrm{K}_{2} \mathrm{SO}_{4}$ 型構造であると報じている. $\alpha^{\prime}{ }_{\mathrm{H}}$ 相の結 晶構造はいまだに決定されていないが，しかし，同相の 格子定数や粉末 $\mathrm{X}$ 線回折図形の特徵から, その結晶構造 は $\beta-\mathrm{K}_{2} \mathrm{SO}_{4}$ 型であろうと推定されている(6),9),10). $\alpha$ 相 の結晶構造は, Bredig ${ }^{11)}$ がグラセライト $\left(\mathrm{K}_{3} \mathrm{Na}\left(\mathrm{SO}_{4}\right)_{2}\right)$ 型の構造であると推定して以来その詳細は不明であうた

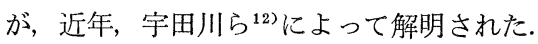

一方，上述した 5 種の多形間の相転移は極めて複雑で あるが，次のような相転移の過程が知られている.すな わち, 加熱過程では $\gamma \rightarrow \alpha^{\prime}{ }_{\mathrm{L}} \rightarrow \alpha^{\prime}{ }_{\mathrm{H}} \rightarrow \alpha$ の経路で相転 移をするが，冷却過程では $\alpha \rightarrow \alpha^{\prime}{ }_{H} \rightarrow \alpha^{\prime}{ }_{L} \rightarrow \beta \rightarrow \gamma$ の 経路で相転移する．なお，この相転移に際して各多形間 に存在する共軸関係に関しては次のような二，三の報告 がなされている. Bridge ${ }^{18)}$ は $\gamma$ 相, $\beta$ 相 (ラーナイト) 及び $\alpha^{\prime}{ }_{\mathrm{L}}$ 相 (ブレジガイト*) の 3 相が共存する天然産 の試料を偏光顕微鏡により観察し，これら結晶相間の共 軸関係を明らかにした. 更に, Saalfeld ${ }^{15)}$ は一つの結晶 粒子中に $\gamma$ 相と $\beta$ 相が共存する試料を作製し，X 線単 結晶法によって両者の共軸関係を求めている. しかしな がら，これらの報告に見られる共軸関係の記載は不完全 であり，また各相間の共軸関係を高温状態で直接測定し た報告はない，純組成の $\mathrm{Ca}_{2} \mathrm{SiO}_{4}$ の高温相は室温まで保 持することはできないが，適当な安定剤を添加すること によりそれらを安定化することは可能である.しかし， 共軸関係を知るためには一つの結晶粒子内に 2 相以上が

* 最近, 結晶構造解析の結果から,ブレジガイトは $\alpha^{\prime}{ }_{\mathrm{L}}-\mathrm{Ca}_{2} \mathrm{SiO}_{4}$ と異なる構造であると報じられている:4).
共存する試料を作製することが必要であり，この ような試料を作製することは極めて困難である. そこで著者らは, 当研究室で開発した高温単結晶 カメラ(16)を用い， $\mathrm{Ca}_{2} \mathrm{SiO}_{4}$ の相転移における各多 形間の共軸関係を高温状態で直接測定することを 試みた. 高温単結晶カメラの使用上限温度の関係 で， $\alpha$ 相の安定領域まで試料を加熱することはで きなかったが，その他の各相の相転移における共 軸関係を直接観察することに成功した．本報では その結果を述べ，更に，この共軸関係と各多形の 結晶構造から， $\mathrm{Ca}_{2} \mathrm{SiO}_{4}$ の相転移機構を原子移動 の面から考察した.

\section{2. 実 験 方 法}

相転移における共軸関係を求めるため, 当研究室で開 発した高温プリセッションカメラを用いて単結晶を所定 の温度で加熱し, 高温状態で特定な逆格子面上のX線回 折はん点を測定した. $\mathrm{X}$ 線源として $\mathrm{Mo} \mathrm{K}_{\alpha}$ 線を用い, 露出時間はそれぞれ約 2 時間であった. $\gamma$ 相, $\beta$ 相, $\alpha^{\prime}{ }_{L}$ 相の各単結晶を出発試料として用いた.

r相の作製方法は既報 ${ }^{17)}$ のとおりである.すなわち, 粉末状の $\gamma$ 相とフラックス $\left(\mathrm{CaCl}_{2}\right)$ とを混合して白金 るつぼ中に入れ， $1300^{\circ} \sim 1500^{\circ} \mathrm{C}$ の温度範囲の所定温度 で加熱保持を行って単結晶を育成した. この $\gamma$ 相単結晶 を用いて $\gamma \rightarrow \alpha^{\prime}{ }_{L} \rightarrow \beta \rightarrow \gamma$ 相転移を高温プリセッショ ンカメラで追跡し，共軸関係を調べた.

ß相の単結晶は次の方法で作製した. $\mathrm{Al}_{2} \mathrm{O}_{3}$ を $2 \mathrm{wt} \%$ 添加して得た安定化した $\beta$ 相の粉末に $\mathrm{CaCl}_{2}$ をフラッ クスとして加え，白金るつぼ中で $1400^{\circ} \mathrm{C}$ で加熱保持を 行って単結晶を育成した ${ }^{5), 6)}$. この $\beta$ 相単結晶を用いて $\beta \rightarrow \alpha^{\prime}{ }_{L} \rightarrow \beta$ 相転移における共軸関係を前述と同様の方 法で求めた.

$\alpha^{\prime}{ }_{\mathrm{L}}$ 相の単結晶の作製は $\beta$ 相のそれに準じて行った. まず，Caの 15 mol\% を $\mathrm{Sr}$ で置換し，安定化した $\alpha^{\prime} \mathrm{L}$ 粉末を合成した. 次に, このようにして得られた $\alpha^{\prime}{ }_{L}{ }$ 粉 末にフラックスとして $\mathrm{SrCl}_{2}$ を添加し, 白金るつぼ中で $1400^{\circ} \mathrm{C}$ で加熱保持を行い単結晶を育成した ${ }^{9)}$. この $\alpha^{\prime} \mathrm{L}$ 相単結晶を用いて $\alpha^{\prime}{ }_{\mathrm{L}} \rightarrow \alpha^{\prime}{ }_{\mathrm{H}}$ 相転移を高温プリセッシ ョンカメラで調べた.

高温状態で X線単結晶写真を撮影するに際して，まず 結晶を高温プリセッションカメラのゴニオメーター・ヘ ッドに固定する必要がある.これには種々の方法が考え られるが，本実験では次の方法を採用した．まず，結晶 を石英ガラス棒（直径約 $0.2 \mathrm{~mm}$ ）の先端に多量の石英 ガラス粉を混ぜたエポキシ樹脂で接着し，これをゴニオ メーター・ヘッドに固定した. 次いで, これを $400^{\circ} \mathrm{C} に$ 加熱し, エポキシ樹脂を分解させた. 


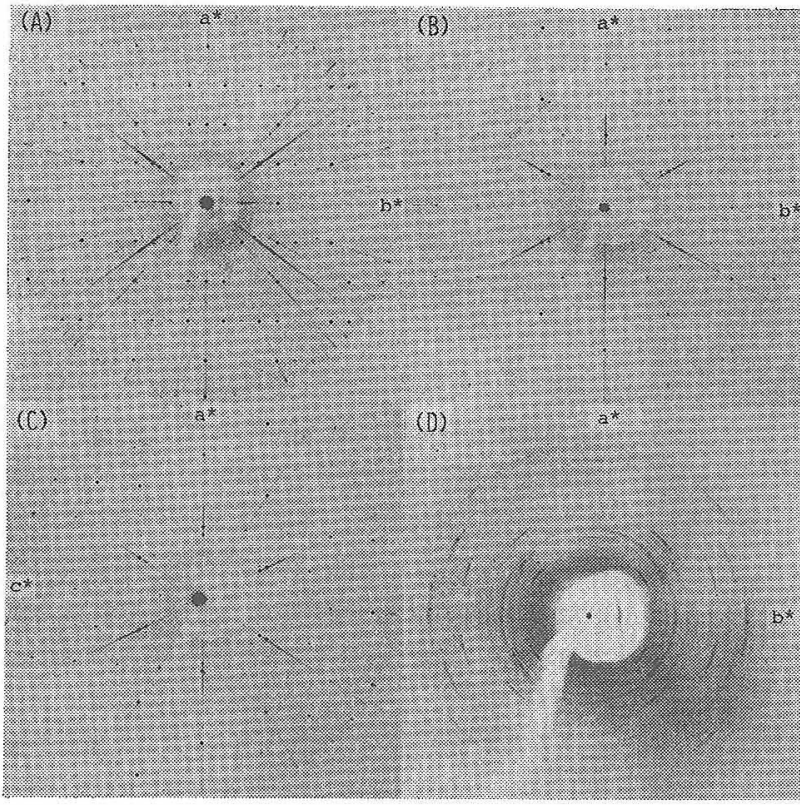

Fig. 1. Precession photographs taken at given temperatures, showing the topotaxial relations among $\gamma_{-}, \alpha^{\prime} L^{-}$and $\beta$-phase.

(A) : At $20^{\circ} \mathrm{C}, a^{*}-b^{*}$ reciprocal plane of $\gamma$-phase (zero layer).

(B) : At $800^{\circ} \mathrm{C}, a^{*}-b^{*}$ reciprocal plane of $\alpha^{\prime}$ L-phase (zero layer).

(C) : At $350^{\circ} \mathrm{C}, a^{*}-c^{*}$ reciprocal plane of $\beta$-phase (zero layer).

(D) : Precession photograph of the $\gamma$-phase crystal with cracks caused by the $\beta \rightarrow \gamma$ phase transition, $a^{*}-b^{*}$ recip. rocal plane of $\gamma$-phase (zero layer).

\section{3. 実 験 結 果}

\section{$3.1 \gamma \rightarrow \alpha^{\prime}{ }_{L} \rightarrow \beta \rightarrow \gamma$ 相転移}

$\gamma$ 相の $c$ 軸を歳差軸として $a^{*}-b^{*}$ 逆格子面の撮影が 可能なように軸合わせを行い，まず室温でプリセッショ ン写真 (図1 (A)) を撮影した. その後 $800^{\circ} \mathrm{C}$ まで昇温 し， $\alpha^{\prime}$ L 相のプリセッション写真（図 1 (B)) を撮影し た. 写真 (図 1 (B)) では，回折はん点の分裂は認めら れず,このことから， $\gamma \rightarrow \alpha^{\prime} \mathrm{L}$ 相転移は約 $9 \%$ の体積減 少を伴うにもかかわらず結晶が破壊していないことが明 らかとなった，次に， $800^{\circ} \mathrm{C}$ より徐々に温度を下げ， $350^{\circ} \mathrm{C}$ で $\beta$ 相のプリセッション写真（図1(C)) を撮影 した. 図 1 (C) は, 3 相の $a^{*}-c^{*}$ 逆梦子面 0 層の写真 であるが，回折はん点の分裂は認められない。したが。 $\tau, \alpha_{L}^{\prime} \rightarrow \beta$ 相転移において 様，結晶は破燷していないことが明らかである。またこ の相転移により 8 相に（100）双晶がしばしば現れるこ とが報じられているが88,18)，本実験においてはこの種の 双晶は現れなかった。

次にプリセッションカメラに付属している顕微鏡で結
晶を観察しながら温度を徐々に下げていくと， $210^{\circ} \mathrm{C}$ で $\beta \rightarrow \gamma$ 相転移が起こり，この相転移に 伴う結晶の破壞のため結晶が不透明になる現象が 諗められた。図 1 (D) は $\beta \rightarrow \gamma$ 相転移によって もとの結晶粒が破壊された状態で生成した プリセッション写真である。すなわち，結晶は $\beta$ $\rightarrow \gamma$ 相転移によって破壞して $\gamma$ 相の小さな結晶の 集合体となるが，生じた個々の結晶粒子の方位に 規則性が認められる。図 1 (D) のプリセッション 写真に認められた回折はん点をやや模式化して図 2 に示した。同図より 秩序に配列するのではなく，もとの $\beta$ 相と一定の 共軸関係を保持していることが明らかとなった。

上述の実験で得られた共軸関係を表 2 に示す。

\section{$3.2 \beta \rightarrow \sigma_{L}^{\prime} \rightarrow \beta$ 相転移}

図 3 (A) は室温で撮影した Al で安定化した $\beta$ 相の $a^{*}-c^{*}$ 逆格子面 0 層のプリセッション写真で ある. 図 $3(\mathrm{~B})$ は $750^{\circ} \mathrm{C}$ で撮影したプリセッシ ヨン写真であり， $\alpha^{\prime} \mathrm{L}$ 相の $a^{*}-b^{*}$ 逆格子面 0 層 の回折は九点が認められる. 図 3 (D) は同じく

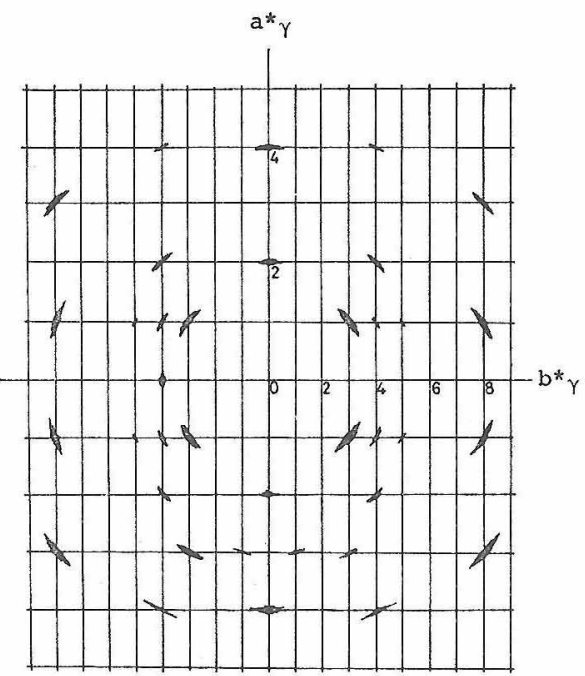

Fig. 2. A schematic illustration of the reflections observed on the precession photograph shown in Fig. 1(D).

Table 2. Topotaxial relations among $\gamma_{-}, \alpha_{L_{-}-}$, $\alpha^{\prime} \mathrm{H}^{-}$and $\beta$-phase of $\mathrm{Ca}_{2} \mathrm{SiO}_{4}$ obtained by $\mathrm{X}$-ray single crystal method.

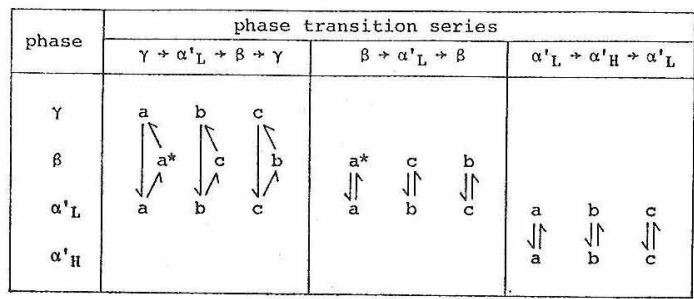


$750^{\circ} \mathrm{C}$ で撮影した $b^{*}-c^{*}$ 逆格子面 1 層の写真であり, $c^{*}$ 軸方向に図中矢印で示した超格子反射が認められる。こ の超格子の周期は基本格子の $c$ 軸方向の周期の 3 倍であ り，Saalfeld ${ }^{8)}$ が報告した結果と一致している. 次に,

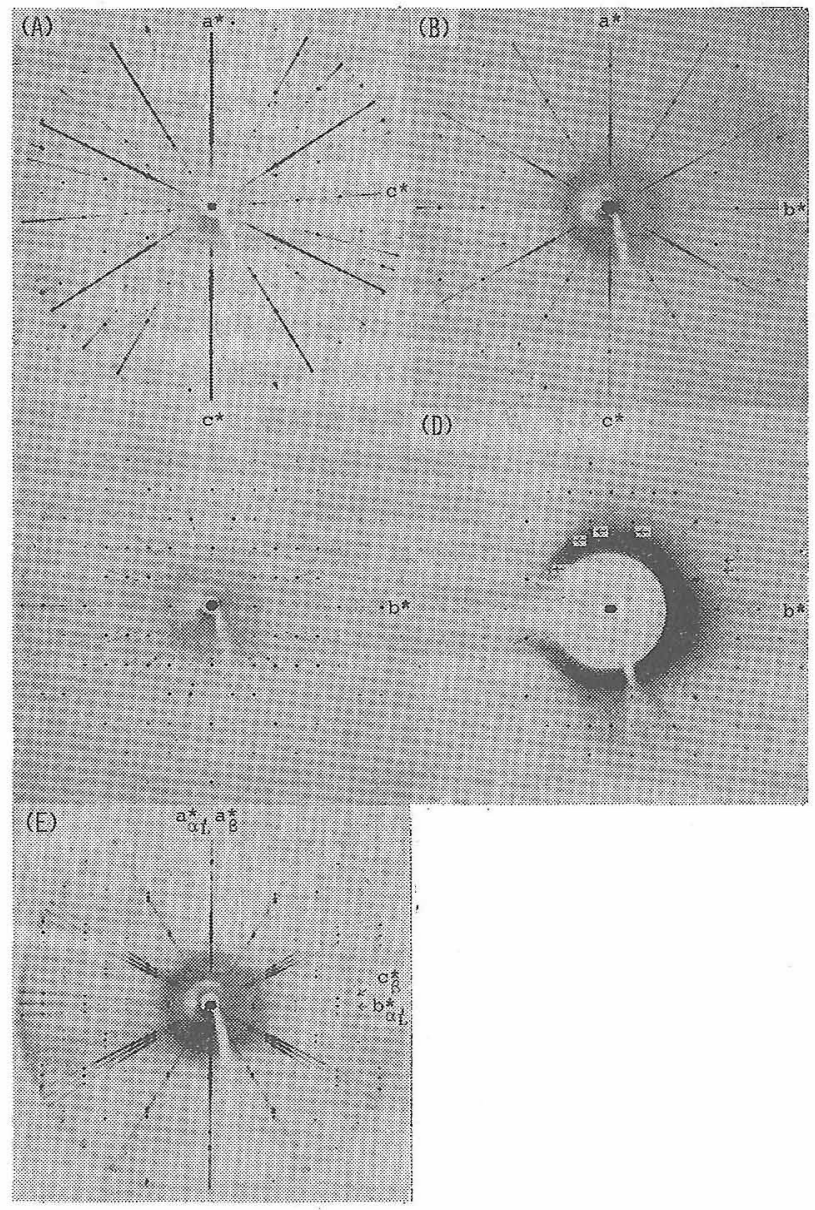

Fig. 3. Precession photographs taken at given temperatures, showing the topotaxial relations between $\beta$ - and $\alpha^{\prime}{ }_{L}$-phase.

(A) : At $20^{\circ} \mathrm{C}, a^{*}-c^{*}$ reciprocal plane of $\beta$-phase (zero layer).

(B) : At $750^{\circ} \mathrm{C}, a^{*}-b^{*}$ reciprocal plane of $\alpha^{\prime}$ L-phase (zero layer).

(C) : At $750^{\circ} \mathrm{C}, b^{*}-c^{*}$ reciprocal plane of $\alpha^{\prime}$ L-phase (zero layer).

(D) : At $750^{\circ} \mathrm{C}, b^{*}-c^{*}$ reciprocal plane of $\alpha^{\prime} L$-phase (first layer). Superstructure reflections along $c$-axis shown with arrows are clearly observed.

(E) : A superimposed photograph exposed at $750^{\circ} \mathrm{C}$ and at $650^{\circ} \mathrm{C}$. Both the $a^{*}-b^{*}$ reciprocal plane of $\alpha^{\prime} L$-phase (zero layer) and the $a^{*}-c^{*}$ reciprocal plane of $\beta$-phase (zero layer) are observed. (100) twin of the $\beta$-phase is observed on the photograph. $750^{\circ} \mathrm{C}$ で $\alpha^{\prime}{ }_{\mathrm{L}}$ 相の写真を撮影した後, 徐々に温度を降 下させ， $650^{\circ} \mathrm{C}$ で同一フィルム上に 2 重露出させたプリ セッション写真を図 3 (E) に示す。同写真には $\alpha^{\prime}{ }_{L}$ 相 の $a^{*}-b^{*}$ 逆格子面 0 層と $\beta$ 相の $a^{*}-c^{*}$ 逆格子面 0 層

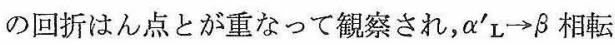
移における両相の共軸関係が明確に分る。また $\alpha^{\prime} \mathrm{L}$ 相加ら相転移によって生成した $\beta$ 相は（100） 双晶となっていることが明らかとなった。得られ た共軸関係を表 2 亿示す。

\section{$3.3 \alpha \alpha_{\mathrm{L}}^{\prime} \rightarrow a_{\mathrm{H}}^{\prime}$ 相転移}

Sr で安定化させた $\alpha^{\prime}{ }_{\mathrm{L}}$ 相の $\alpha^{\prime}{ }_{\mathrm{L}} \rightarrow \alpha^{\prime}{ }_{\mathrm{H}}$ 相転 移の䎐移温度は純粋な $\mathrm{Ca}_{2} \mathrm{SiO}_{4}$ 組成のそれより低 い温度となることが知られている199. 本研究で用 いた $\alpha_{L}^{\prime}$ 相は $\mathrm{Ca}$ の約 $17 \%$ が $\mathrm{Sr}$ で置換され ておりり，このためその $\alpha^{\prime}{ }_{\mathrm{H}}$ 相への転移温度は $1000^{\circ} \mathrm{C}$ 付近であろうと推定される。室温で $\alpha^{\prime} \mathrm{L}$ 相の $b$ 軸を歳差軸としたプリセッション写真を撮

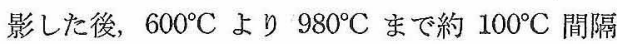
の各温度段階で次々とプリセッション写真を撮影 した，図4 (A) は室温で撮影したプリセッション 写真, 図 4 (B) は $980^{\circ} \mathrm{C}$ にて撮影したものであ る. 図 $4(\mathrm{~A})$ に注 $\alpha^{\prime} \mathrm{L}$ 相の特街である $c^{*}$ 軸方 向の超格子反射が認められる. 加熱温度の上昇に 伴い，この超格子反射の回折強度は弱くなり，図 4 (B) に示したプリセッション写真には超格子反 射が認められない，したがって，この温度 $\left(980^{\circ} \mathrm{C}\right)$ では $\alpha^{\prime}{ }_{\mathrm{H}}$ 相に変化していることが明らかである． $\alpha^{\prime} \mathrm{L} \rightarrow \alpha^{\prime} \mathrm{H}$ 相転移に括行る共軸関係を表 2 に示 す. 更に表 2 に示した共軸関係をまとめて, 図 5 に示した.

\section{4. 相 転移機構}

Smith ら ${ }^{200}$ は $\gamma$ 相の結晶構造解析を行い，その 結果と, 当時知られていた $\mathrm{Ca}_{2} \mathrm{SiO}_{4}$ のその他の多 形の結晶構造を基に相転移の機構を考察した. し かし，結晶構造及び共軸関係に関する情報が不十 分であったため，これには幾つかの誤りが認めら れる. Eysel ら ${ }^{21)} も こ の$ 相転移機構について諭じ ているが，相転移に関与する各相間の共軸関係を 考慮しておらず，これにも Smith ら ${ }^{200}$ と同榚の 愦りが認められる。 そこで，本研究で確立された $\mathrm{Ca}_{2} \mathrm{SiO}_{4}$ の相転移に抒ける共軸関係及び結晶構造 に関する最新の情報4 (6),99,12）を基に，この相転移 の機構を改めて考察した。

$\gamma$ 相は図 6 (A) に示寸ようにオリビン型構造を とる.この構造は酸素の六方密充てん配列加ら導 くことができ，酸素のパッキング面は $b-c$ 面に 相当する。また， $\alpha^{\prime}{ }_{\mathrm{H}} ＼alpha^{p}$ 工 及び $\beta$ 相はいずれも 


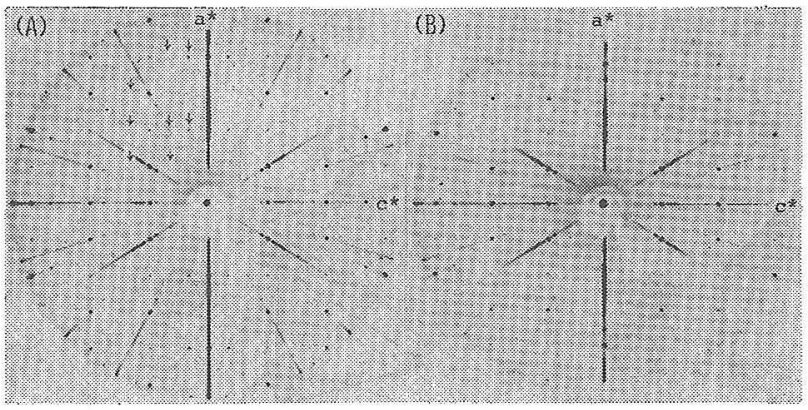

Fig. 4. Precession photographs taken at given temperatures, showing the topotaxial relations between $\alpha^{\prime} \mathrm{L}^{-}$and $\alpha_{\mathrm{H} \text {-phase. }}$

(A) : At $20^{\circ} \mathrm{C}, a^{*}-c^{*}$ reciprocal plane of $\alpha_{L}^{\prime}$-phase (zero layer). Superstructure reflections shown with arrows are observed.

(B) : At $980^{\circ} \mathrm{C}, a^{*}-c^{*}$ reciprocal plane of $\alpha^{\prime}{ }_{H}$-phase (zero layer). Superstructure reflections are disappeared.

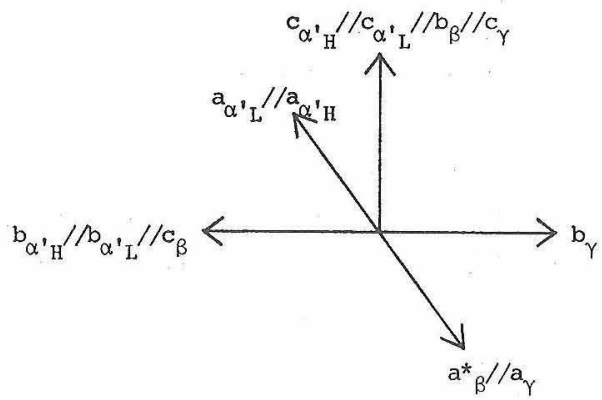

Fig. 5. Illustration of the topotaxial relations among $\gamma_{-}, \alpha_{L^{-}}^{\prime}, \alpha_{H^{-}}^{\prime}$ and $\beta$-phase of $\mathrm{Ca}_{2} \mathrm{SiO}_{4}$.

(A) $\quad \mathrm{\gamma}-\mathrm{Ca}_{2} \mathrm{SiO}_{4}$

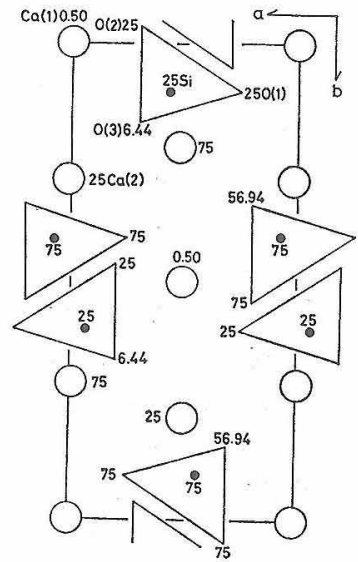

(B) $\mathrm{B}-\mathrm{Ca}_{2} \mathrm{SiO}$

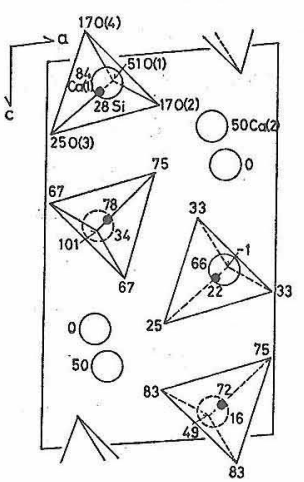

$\beta-\mathrm{K}_{2} \mathrm{SO}_{4}$ 型構造であり， $\gamma$ 相と同様に酸素の六方 密充てん配列加ら導くことのできる構造である.

酸素の密充てん層は図 $6(\mathrm{C})$ に示した $\alpha^{\prime}{ }_{\mathrm{L}}$ 相の $a-b$ 面に相当する。 $\gamma \rightarrow \alpha^{\prime} \mathrm{L}$ 相転移では，表 2 及 び図 5 に示した共軸関係と両相の結晶構造との比 較加ら，図 7 (A) に示寸原子の移動片式が考えら れる。この相転移では $\mathrm{Ca}$ 原子はわずかに移動 し， $\mathrm{SiO}_{4} 4$ 面体は回転し，かつ移動子ると考光 られる。この変化により，体積が約 $9 \%$ 収縮し更 に両相の酸素密充てん層は直交する関係になる。

Ca 原子は $\gamma$ 相では 6 配位であったが $\alpha^{\prime}$ L 相で は 7 及び 10 配位となる ${ }^{6), 9}$ 。上述の相転移の機構 は, Smith ら ${ }^{20)}$ 及び Eysel ら ${ }^{21)}$ の示した酸素のパ ッキング面が相転移前後の両相において共有され るという機構とは異なるものであり，Saalfeld ${ }^{15\rangle}$ が $\gamma$ 相と $\beta$ 相との共軸関係から予想した相転移機

構に近いものである.

$\alpha^{\prime}{ }_{\mathrm{L}} \rightarrow \alpha^{\prime}{ }_{\mathrm{H}}$ 相転移では， $\alpha^{\prime} \mathrm{L}$ 相の超格子反射の 強度が温度の上昇とともに次第に減少し，ついに全く認 められなくなる現象が観測された。 $\alpha^{\prime} \mathrm{L}$ 相の超格子反射 は，図 6 (C)，(D)より明らかなように，その構造が $\alpha_{\mathrm{H}}$ 相の構造からわずかにずれていることに起因している9 . したがって $\alpha^{\prime} \mathrm{L}$ 相の超格子反射の強度が温度の上昇に 伴って減少することは，結晶檴造中の $\mathrm{SiO}_{4} 4$ 面体の傾 きや， $\mathrm{Ca}$ 原子の理想的位置からの変化が小さくなるこ とに対応していると考えられる。上述のことから明らか なようにここの相転移は極めてわずかな原子移動で完了 する.

図 7 (B) に $\alpha^{\prime}{ }_{L} \rightarrow \beta$ 相転移で考元られる原子の移動 方式の一例を示寸。この相転移では約 $2 \%$ 体積が収縮す る. $\alpha^{\prime}{ }_{\mathrm{L}}$ 相の $\mathrm{SiO}_{4} 4$ 面体の傾きに着目すると, $c$ 軸方
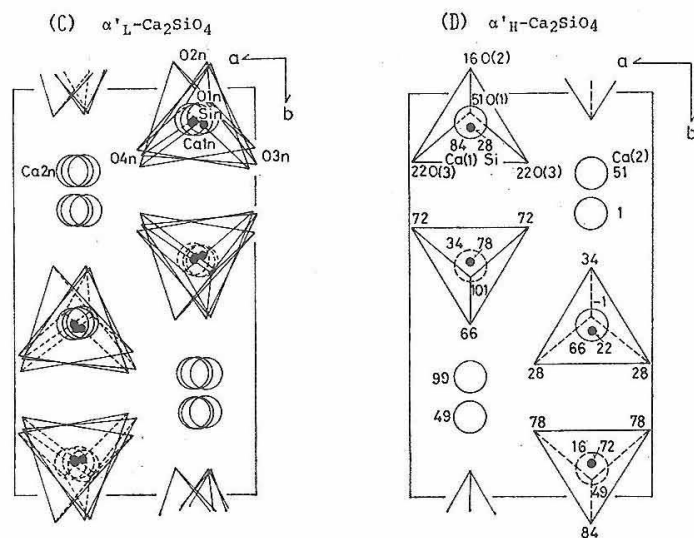

Fig. 6. Related projections of the crystal structures of four modifications of $\mathrm{Ca}_{2} \mathrm{SiO}_{4}$. Heights are marked on the appropriate atoms. $\mathrm{Ca}$ : Large open circle, $\mathrm{Si}:$ Small closed circle.

(A) : $\gamma-\mathrm{Ca}_{2} \mathrm{SiO}_{4}$ projected on (001).

(B) : $\beta-\mathrm{Ca}_{2} \mathrm{SiO}_{4}$ projected on (010).

(C) : $\alpha^{\prime}{ }_{\mathrm{L}}-\mathrm{Ca}_{2} \mathrm{SiO}_{4}$ projected on (001).

(D) : An expected $\alpha^{\prime} \mathrm{H}^{-} \mathrm{Ca}_{2} \mathrm{SiO}_{4}$ projected on (001). 
(A) $\quad \gamma+\alpha^{\prime}{ }_{L}$

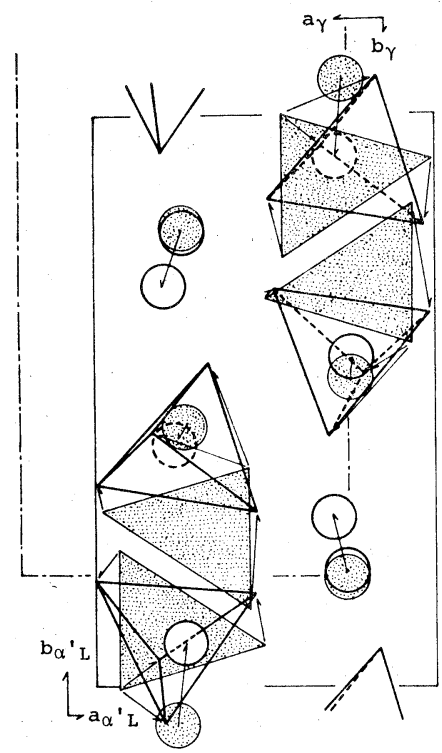

(B) $\quad \alpha^{\prime}{ }_{L} \leftrightarrow \beta$

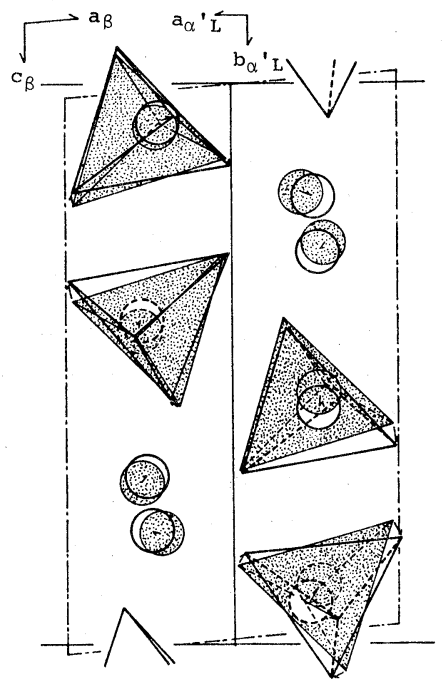

(C) $\beta+\gamma$

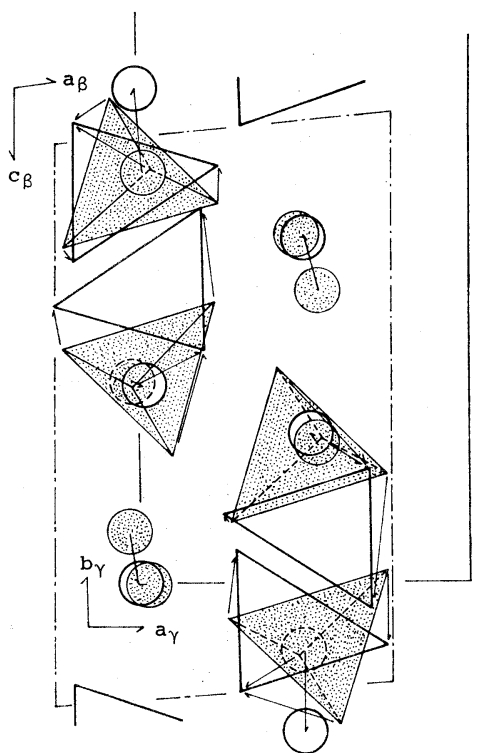

Fig. 7. The movements of atoms supposed to take place during the phase transitions of $\mathrm{Ca}_{2} \mathrm{SiO}_{4}$. (A) $: \gamma \rightarrow \alpha^{\prime}{ }_{\mathrm{L}}$ transition. The $\mathrm{Ca}$ atoms and the tetrahedra in $\gamma-\mathrm{Ca}_{2} \mathrm{SiO}_{4}$ are hatched.

(B) : $\alpha^{\prime}{ }_{\mathrm{L}} \leftrightarrow \beta$ transition. The $\mathrm{Ca}$ atoms and the tetrahedra in $\beta-\mathrm{Ca}_{2} \mathrm{SiO}_{4}$ are hatched.

(C) : $\beta \rightarrow \gamma$ transition. The $\mathrm{Ca}$ atoms and the tetrahedra in $\beta-\mathrm{Ca}_{2} \mathrm{SiO}_{4}$ are hatched.

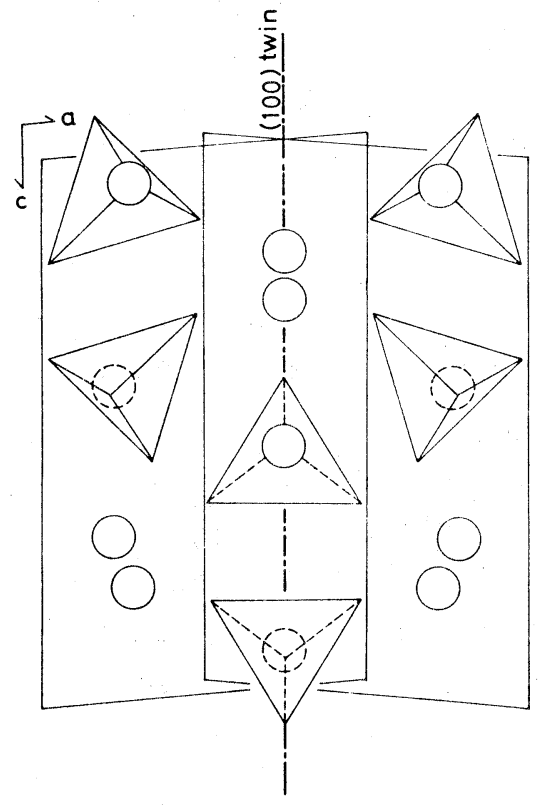

Fig. 8. A structure model of the twin boundary on (100) for $\beta$-phase.

向の超格子のうち, $c=0 \sim 1 / 3$ 及び $c=2 / 3 \sim 1$ の格子内 の配列は $\beta$ 相のそれに近似しており，かつ互いに対掌的 (enantiomorphous) な関係にある(図 $6(\mathrm{C})$ )。したが って, $\alpha_{\mathrm{L}}^{\prime} \rightarrow \beta$ 相転移に㧊いて, 図 7(B) に示した原子 の移動方式とこれと対掌関係の移動方式とが同一の確率
で可能であると考えられる．上述の両移動方式で相転移 が起こるとするならば，生成する $\beta$ 相は図 8 亿示すよ うに(100) 双晶となる．またこの相転移では結晶系が斜 方晶系から単斜晶系へと変化する. $\alpha^{\prime}{ }_{\mathrm{L}}$ 相の $a$ 軸と $\beta$ 相 の $a$ 軸との交わる角度は $4.6^{\circ}$ である. 結晶内の任意の 点を原点と考えたとき，この原点の近傍では図 7 (B) に 示したように，相転移の際の原子移動はわずかですむ.

しかし原点から離れるにしたがって $\alpha^{\prime}{ }_{\mathrm{L}}$ 相の $a$ 軸と $\beta$ 相の $a$ 軸との隔たりは大きくなり, このため原子の移動 距離も大きくなる。ここで $(100)$ 双晶が発生すれば, 両 者の結晶軸間の隔たりは少なくなり，したがって原子の 移動距離が小さくなる．このことが $\alpha^{\prime}{ }_{L} \rightarrow \beta$ 相転移で (100) 双晶が発生する理由であろう。上述のように, $\alpha^{\prime}{ }_{\mathrm{H}}, \alpha^{\prime} \mathrm{L}, \beta$ 相の結晶構造は相互に近似しているので, $\alpha^{\prime}{ }_{H} \leftrightarrow \alpha^{\prime}{ }_{L} \leftrightarrow \beta$ 相転移は極めてわずかの原子移動で完了 する型の相転移である.

図 7 (C) に $\beta \rightarrow \gamma$ 相転移の際に起こると考えられる 原子の移動方式を示寸. この相転移では $\mathrm{SiO}_{4} 4$ 面体は 回転し，かつ並進することが必要である。この相転移に より, 単斜晶系から斜方晶系へと結晶系が変化し, 約 $12 \%$ 体積が膨張し結晶は小さく破壊して，相転移前の 結晶が小さい場合にはいわゆる“ダスティング現象”を 示す.しかし，小さな結晶に破壊した後の $\gamma$ 相結晶の結 晶学的方位は, 図 1 (D) に示したようにほとんど乱され ていない， $\gamma$ 相の結晶を顕微鏡下で観察すると， (100) 面でへき開し $c$ 軸方向に伸長した結晶片が多数観察され 


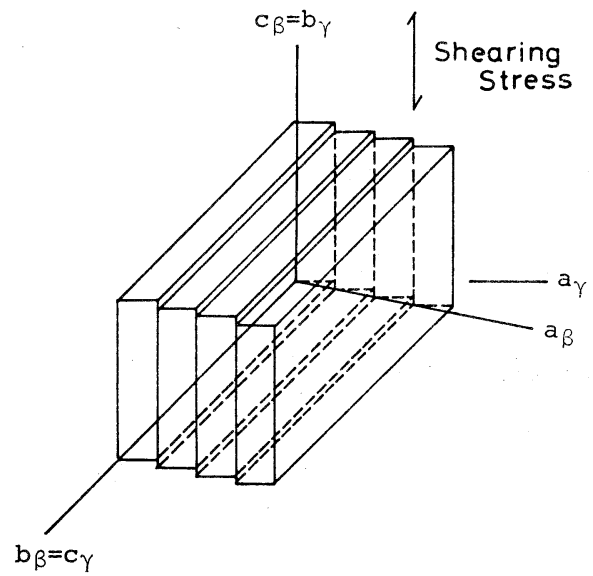

Fig. 9. Schematic drawing for the explanation of the breaking phenomena of the crystal of $\gamma$-phase in the $\beta \rightarrow \gamma$ phase transition.

る.上述のことから，図 9に示すダスティング機構が考 えられる，すなわち， $\beta \rightarrow \gamma$ 相転移における結晶格子の 膨張は主として $\beta$ 相の $b-c$ 面内で起こる. このため $\gamma$ 相の生成に当たり，この面内にせん断応力が発生すると 考えられる. 一方, $\beta$ 相の $a$ 軸と $\gamma$ 相の $a$ 軸とは $4.6^{\circ}$ の角度で交差する関係にある，いま，相転移に際してこ の角度が解消されるとすると，このことからも $\beta$ 相の $b-c$ 面間にせん断応力が発生すると考えられる. これら 二つの理由によるせん断応力の発生の結果, 結晶の (100) 面で破壊が起こり，生成した $\gamma$ 相は（100）面でへき開 したへん平な結晶片となるものと推察される、いま，も との $\beta$ 結晶が小さい場合には, この相転移に伴う結晶相 破壊のためより小さな $\gamma$ 相結晶となり，粉塵化する．こ れがセメントに拉けるいわゆる “ダスティング (dusting）現象”である.

$\alpha$ 相と $\alpha^{\prime}{ }_{\mathrm{H}}$ 相との共軸関係を直接明らかにした報告 はない。しかし， $\alpha$ 相は分域構造であり，また各分域は $c$ 軸の周りで $120^{\circ}$ 回転すると互いに同位する関係にあ る ${ }^{122}$. したがって， $\alpha^{\prime}{ }_{\mathrm{H}} \rightarrow \alpha$ 相転移は， $\alpha^{\prime}{ }_{\mathrm{H}}$ 相が $\alpha$ 相に 特有な分域構造に変化することに対応していると考えら れる. $\alpha \rightarrow \alpha^{\prime}{ }_{\mathrm{H}}$ 相転移では， $\alpha$ 相の中に存在する 3 種の 分域の各々が，それぞれ特定な方位の $\alpha^{\prime}{ }_{\mathrm{H}}$ 相へ変化す ることが考えられ，その結果，生成した $\alpha^{\prime}{ }_{\mathrm{H}}$ 相は $c$ 軸 を $120^{\circ}$ の双晶軸とする輪転双晶 ${ }^{22}$ となると考えられる.

\section{5. 総 括}

$\mathrm{Ca}_{2} \mathrm{SiO}_{4}$ の多形間の相転移を高温プリセッションカメ ラを用いて直接測定して次の結果を得た.

(1) $\gamma \rightarrow \alpha^{\prime}{ }_{\mathrm{L}}$ 相転移では, $a_{\gamma} / / a_{\alpha^{\prime} \mathrm{L}}, b_{\gamma} / / b_{\alpha^{\prime} \mathrm{L}}, c_{\gamma} / / c_{\alpha^{\prime} \mathrm{L}}$ の共軸関係が保たれる. なお，相転移に伴う結晶の破壊 は起こらない。
(2) $\alpha_{\mathrm{L}}^{\prime} \rightarrow \alpha_{\mathrm{H}}^{\prime}$ 相転移 では $a_{\alpha^{\prime} \mathrm{L}} / / a_{\alpha^{\prime} \mathrm{H}}, b_{\alpha^{\prime} \mathrm{L}} / / b_{\alpha^{\prime} \mathrm{H}}$, $c_{\alpha^{\prime} \mathrm{L}} / / c_{\alpha^{\prime} \mathrm{H}}$ の共軸関係が保たれる。 なお， $\alpha_{\mathrm{L}}^{\prime}$ 相の超格 子反射の回折強度は温度の上昇とともに減少する.

(3) $\alpha_{\mathrm{L}}^{\prime} \rightarrow \beta$ 相転移では $a_{\alpha^{\prime} \mathrm{L}} / / a^{*}{ }_{\beta}, b_{\alpha^{\prime} \mathrm{L}} / / c_{\beta}, c_{\alpha^{\prime} \mathrm{L}} / / b_{\beta}$ の共軸関係があり，生成した $\beta$ 相には (100) 双晶がしば しば現れる。

（4） $\beta \rightarrow \gamma$ 相転移では，結晶は破壊するが $a^{*}{ }_{\beta} / / a_{\gamma}$ ， $b_{\beta} / / c_{\gamma}, c_{\beta} / / b_{\gamma}$ の共軸関係が保たれる.

上述の共軸関倸及び著者らによる $\mathrm{Ca}_{2} \mathrm{SiO}_{4}$ の各多形の 結晶構造解析の結果に基づき，相転移に関与する両相の $\mathrm{SiO}_{4} 4$ 面体, 及び $\mathrm{Ca}$ 原子の幾何学的な位置関係に着 目し，相転移の機構を考察した。

謝辞 本研究の遂行に当たり，有意義な御意見，御検討 を頂いた東京工業大学工学部助手井川博行博士に感謝致します. また高温プリセッション写真の撮影に御協力頂いた東京工業大 学工学部高田和哉氏 (現, 徳山曹達 (株)) に謝意を表します.

\section{文献}

1) A. Guinier and M. Regourd, Proc. Fifth Internat. Symp. Chemistry of Cement, I , 1-32 (1968).

2) L. Liu, Phys. Chem. Mineral., 3, 291-99 (1978).

3) C.M. Midgley, Acta Cryst., 5, 307-12 (1952).

4) K.H. Jost, B. Ziemer and R. Seydel, Acta Cryst., B 33, 1696-1700 (1977).

5）宇田川重和, 浦部和順, 矢野豊彦, セメントコンクリー 卜九州討論会講演予稿集, 3-4 (1977).

6）宇田川重和，浦部和順，セメント技術年報，32，35-38 (1978).

7) M. Regourd, M. Bigaré, J. Forest and A. Guinier, Proc. Fifth Internat. Symp. Chemistry of Cement, I, 44-48 (1968).

8) H. Saalfeld, Am. Mineral., 60, 824-27 (1975).

9）宇田川重和, 浦部和順, 矢野豊彦, 高田和哉, 夏目幹子, セメント技術年報，33，21-24（1979).

10) M.A. Bredig, J. Am. Ceram. Soc., 33, 188-92 (1950).

11) M.A. Bredig, J. Phys. Chem., 46, 747-64 (1942).

12）宇田川重和，浦部和順，矢野豊彦，七メント技術年報， 31, 26-29 (1977).

13) T.E. Bridge, Am. Mineral., 51, 1766-74 (1966).

14) P.B. Moore and T. Araki, Am. Mineral., 61, 74-87 (1976).

15) H. Saalfeld, Ber. Deut. Keram. Ges., 30, 185-89 (1953).

16）宇田川重和, 井川博行, 浦部和順, 山本博一, 矢野豊彦, 材料科学, 16, 271-75 (1979).

17）宇田川重和，浦部和順，片山恵一，七メント技術年報， 30, 37-41 (1976).

18) Y. Ono, S. Kawamura and Y. Soda, Proc. Fifth Internat. Symp. Chemistry of Cement, I , 275-84 (1968).

19） K. Suzuki, I. Huruhashi and H. Hukui，㝘協，79, 199-208 (1971).

20) D.K. Smith, A. Majumdar and F. Ordway, Acta Cryst., 18, 787-95 (1965).

21) W. Eysel and T. Hahn, Zeit. Krist., 131, 322-41 (1970).

22) H. Saalfeld, Ber. Deut. Keram. Ges., 44, 279-83 (1967). 